\title{
Strengthening Primary Care Through Family Medicine Around the World: Collaborating Toward Promising Practices
}

\author{
Katherine Rouleau, MD; Monique Bourget, MD; Patrick Chege, MD; Francois Couturier, MD; \\ Paula Godoy-Ruiz, PhD; Paul H. Grand'Maison, MD; Melanie Henry, MD; Kerling Israel, MD; \\ Videsh Kapoor, MD;Hendra Kurniawan, MD; Louella Lobo, MD; Mahamane Maiga, MD; \\ Samantha Pereira Franca, MD; Lynda Redwood-Campbell, MD; Jamie Rodas, MPH; \\ Raman Sohal, MA, MBA; Dawit Wondimagegn, MD; Robert Woollard, MD
}

BACKGROUND AND OBJECTIVES: There is a limited evidentiary base on the development of family medicine in different contexts and countries. The lack of evidence impedes our ability to compare and characterize family medicine models and identify areas of success that have led to the effective provision of care. This paper offers a comparative compilation and analysis of the development of family medicine training programs in seven countries: Brazil, Canada, Ethiopia, Haiti, Indonesia, Kenya, and Mali.

METHODS: Using qualitative case studies, this paper examines the process of developing family medicine programs, including enabling strategies and barriers, and shared lessons. An appreciative inquiry framework and complex adaptive systems thinking inform our qualitative study.

RESULTS: Committed partnerships, the contribution of champions, health policy, and adaptability were identified as key enablers in all seven case studies. The case studies further reveal that some enablers were more salient in certain contexts as compared to others, and that it is the interaction of enablers that is crucial for understanding how and why initiatives succeeded. The barriers that emerged across the seven case studies include: (1) resistance from other medical specialties, (2) lack of resources and capabilities, (3) difficulty in sustaining support of champions, and (4) challenges in brokering effective partnerships.

CONCLUSIONS: A key insight from this study is that the implementation of family medicine is nonlinear, dynamic, and complex. The findings of this comparative analysis offer insights and strategies that can inform the design and development of family medicine programs elsewhere.

(Fam Med. 2018;50(6):426-36.)

doi: 10.22454/FamMed.2018.210965

Published Online First March 8, 2018

D) etween 1995 and 2015, the number of countries reported to have family medicine training programs grew from 56 to 132. ${ }^{1-2}$ The growth and strengthening of family medicine globally is due in part to evidence linking robust recent global health publications including the World Health Organization (WHO) reports: Primary Health Care: Now More Than Ever and Global Strategy on Human Resources for Health: Workforce 2030., The Sustainable Development Goals (SDGs) and the push for Universal Health Coverage (UHC) also offer synergies for the development of family medicine. Despite clear progress, the development of family medicine in low, middle, and many high-income countries continues to face a wide range of challenges. ${ }^{6}$ One of the unique challenges faced

From the University of Toronto, Department of Family and Community Medicine (Drs Rouleau, Godoy-Ruiz, and Henry, and Ms Rodas); Santa Marcelina Hospital, Faculdade Santa Marcelina, Sao Pãolo, Brazil (Dr Bourget); Moi University College of Health Sciences, Department of Family Medicine (Dr Chege); Université de Sherbrooke, Canada, Faculty of Medicine and Health Sciences (Drs Couturier and Grand'Maison); Partners in Health, Hospital Saint Nicolas, Saint Marc, Haiti (Dr Israel); University of British Columbia (Drs Kapoor and Woollard); Syiah Kuala University Public Health and Community Medicine Department, Aceh, Indonesia (Dr Kurniawan); McMaster University, Department of Family Medicine, Ontario, Canada (Drs Lobo and Redwood-Campbell); DECLIC, Bamako, Mali (Dr Maiga); Municipal Health Department of Rio de Janiero, Brazil (Dr Franca); University of Toronto Institute of Health Policy Management and Evaluation (Ms Sohal); and Addis Ababa University Family Medicine Program, Addis Ababa, Ethiopia (Dr Wondimagegn). 
by champions of family medicine in emerging contexts is the need to convey the conceptual foundations and clinical methods unique to family medicine as a specialty devoted to comprehensive health care for people of all ages, ${ }^{7}$ highlighting the contribution of family medicine and generalism to health systems as distinct, foundational, and complementary rather than competing with specialization.

While global efforts to develop family medicine have been gaining momentum over the past decade, few comparative analyses of family medicine across different countries have been published in the academic literature. This scholarly gap prompted the development of the collaborative research project, Strengthening Primary Care Through Family Medicine Around the World, to examine and compare the process of developing family medicine programs in Canada, Brazil, Ethiopia, Haiti, Indonesia, Kenya, and Mali. This paper presents the results of this project and offers potential strategies that may facilitate the growth of family medicine globally.

\section{Conceptual Framing}

Both appreciative inquiry and complex adaptive thinking systems perspectives informed our study. Appreciative inquiry is a framework for analysis, decision-making, and the creation of strategic change within organizations. Specifically, it is a framework for examining organizational and system practices from the standpoint of what works, by examining past and present strengths and potentials. ${ }^{8,9}$ Complexity theory proposes that change needs to be understood in terms of coevolution with all other related systems, rather than as adaptation to a separate and distinct environment. Complex adaptive systems are dynamic systems able to adapt in and evolve with a changing environment. Given the heterogeneous contexts in which the seven family medicine initiatives were implemented, a theoretical lens premised on tenets of nonlinearity ${ }^{10}$ was particularly relevant for this project.

\section{Methods}

A case study research methodology ${ }^{11}$ was used for gathering data on the development of family medicine and primary care in selected countries. This method is ideal for capturing a process or phenomenon, and for understanding how family medicine implementation works and why it works in a particular way. ${ }^{11}$ Study coinvestigators in Canada, Brazil, Ethiopia, Haiti, Indonesia, Kenya, and Mali were selected through a convenience sample. They included members of the Global Health Committee of the College of Family Physicians of Canada and international collaborators of several academic Canadian Family Medicine Departments. International coinvestigators were known to have been active participants in the implementation of family medicine in their settings. The leads of the case studies were given broad guidelines, but not strict directives regarding the development, length, or content of their case studies. This approach sought to capture the pivotal moments and key elements in the development of the discipline. Authors were encouraged to include information about enablers and challenges, including events, individuals, and circumstances. Two research team members separately analyzed the enablers and challenges presented in each case study and identified key emerging themes. The analyses were compared in order to reach consensus and findings were disseminated to the entire project team for feedback and reflection. This study was reviewed and approved by the Health Sciences Research Ethics Board of the University of Toronto (protocol \#30417).

\section{Results}

To understand the strategies and processes underpinning family medicine implementation, we analyzed case studies to identify enablers and barriers. We created a typology of the enablers, as outlined in
Table 1, dividing them into predisposing, facilitating, and reinforcing enablers. Predisposing enablers (also called factors) are elements that the initiative inherited prior to the establishment of family medicine and were helpful in gaining success (eg, an expressed need for primary care or policy direction on the part of the government, or the school). Facilitating enablers are elements that the initiative and its partners created to advance family medicine as a practice (eg, identifying collaborative partners, resources, etc.). Reinforcing enablers are elements that supported the new initiative once established (eg, relationships, policies and/or resources that made the innovation sustainable).

\section{Enablers}

In considering the complex interplay of factors and the widely diverse trajectory of family medicine development in the seven settings studied, we note four meta-level enablers (Figure 1) common to all seven case studies, namely champions, committed partnerships, health policy, and an adaptability in defining the role of family medicine in a given setting.

\section{Champions: Broker Critical Ties}

All seven case studies point to the key roles played by individual champions in establishing family medicine. Champions, while not always family physicians themselves, acted as family medicine catalysts and facilitators. For example, in Mali, the early commitment of champions from Bamako and Sherbrooke drew attention to the discipline and created a sense of urgency to establish family medicine in a resource-constrained setting. Similarly, after meeting in Bamako, the deans of medicine from the Universities of Sherbrooke and Mali assumed the role of champions themselves, mutually acknowledging the importance of training comprehensive generalist physicians to respond to Mali's health needs. In Ethiopia, a series of champions from Addis Ababa University, supported by others from the University of 
Table 1: Predisposing, Facilitating, and Reinforcing Enablers

Predisposing enablers are those elements that the initiative inherited prior to the establishment of family medicine and were helpful in gaining success (eg, an expressed need for primary care or policy direction on the part of the government, the school, or others). Facilitating enablers are elements that the project and its partners created to advance family medicine as a practice (eg, a venue to build new relationships, collaborative partners, resources, etc). Reinforcing enablers are elements that support the new state of affairs once the initiative was established (eg, relationships, policies, and/or resources that made the innovation sustainable).

\begin{tabular}{|c|c|c|c|}
\hline Country & Predisposing Enablers & Facilitating Enablers & Reinforcing Enablers \\
\hline Brazil & $\begin{array}{l}\text { Several local and } \\
\text { individual initiatives } \\
\text { implemented to } \\
\text { advance community } \\
\text { medicine and } \\
\text { comprehensive care. } \\
\text { Constitutional } \\
\text { reform after } \\
\text { dictatorship } \\
\text { proclaiming universal } \\
\text { health coverage in } \\
\text { 1988 } \\
\text { Health care } \\
\text { reform movement } \\
\text { as reaction to } \\
\text { specialist-driven } \\
\text { model of care. } \\
\text { Influential partners } \\
\text { such as Kellogg's } \\
\text { Foundation and } \\
\text { PAHO sponsored } \\
\text { and supported } \\
\text { various family } \\
\text { medicine initiatives. } \\
\text { PAHO fellowships } \\
\text { for Brazilians to } \\
\text { study public health } \\
\text { in United States. } \\
\text { Fellow Ellis A. } \\
\text { Busnello returned } \\
\text { to Brazil to set up } \\
\text { first family medicine } \\
\text { program in south } \\
\text { Brazil-Murialdo. } \\
\text { Professor Geraldo } \\
\text { Horacio de Souza } \\
\text { founds Faculty of } \\
\text { Public Health at the } \\
\text { University of São } \\
\text { Paulo (USP) and } \\
\text { implements of seeds } \\
\text { of (family medicine) } \\
\text { primary health care } \\
\text { clinic model. }\end{array}$ & $\begin{array}{l}\text { In late 1970s } \\
\text { several family } \\
\text { medicine programs } \\
\text { were established: } \\
\text { three initiatives } \\
\text { implemented that } \\
\text { were informed by } \\
\text { a family medicine } \\
\text { model and logic: (1) } \\
\text { "Serviço de Saúde de } \\
\text { São José do Murialdo" } \\
\text { in Porto Alegre-RS, } \\
\text { (2) "Projeto de Vitória } \\
\text { de Santo Antão-PE" } \\
\text { and (3) the experience } \\
\text { of the "Universidade } \\
\text { Estadual do Rio de } \\
\text { Janeiro" } \\
\text { (UERJ). } \\
\text { Family medicine } \\
\text { recognized in 1981 in } \\
\text { National Commission } \\
\text { for Residency } \\
\text { programs when } \\
\text { the programs were } \\
\text { legalized. } \\
\text { Brazil implements } \\
\text { Family Health } \\
\text { program and Family } \\
\text { Health strategy in } \\
\text { 1990s-two years } \\
\text { after the National } \\
\text { Program for Health } \\
\text { Care Agents had been } \\
\text { created. } \\
\text { First Family Health } \\
\text { Teams (FHTs) } \\
\text { created in a large } \\
\text { metropolitan area in } \\
\text { 1996, which facilitated } \\
\text { expansion primary } \\
\text { care-FHTs now } \\
\text { covers more than } \\
\text { 50\% of the Brazilian } \\
\text { population. }\end{array}$ & $\begin{array}{l}\text { National Guidelines of Medical Education (DCN) } \\
\text { developed by the Ministry of Education focus in } 2001 \\
\text { the formation of generalists and is ratified in } 2014 \text { that } \\
\text { Brazilian universities are to train medical students to } \\
\text { become generalists as their first goal. } \\
2014 \text { DCN increases amount of time devoted to primary } \\
\text { health care in medical internship by } 30 \% \text {. } \\
\text { Ministry of Health and Education in } 2013 \text { implements } \\
\text { More Doctors Law which stipulates that until } 2018 \text { every } \\
\text { graduate is required to do at least one year in a family } \\
\text { residency program. } \\
\text { Strengthened role of Brazilian Society of Family and } \\
\text { Community Medicine (SBMFC) who was fundamental in } \\
\text { the recognition of the specialty in the Federal Council of } \\
\text { Medicine in } 2004 \text { and in qualifying the practice and the } \\
\text { residency programs promoting bi-annual congresses. }\end{array}$ \\
\hline
\end{tabular}


Table 1, continued

\begin{tabular}{|c|c|c|c|}
\hline Country & Predisposing Enablers & Facilitating Enablers & Reinforcing Enablers \\
\hline Ethiopia & $\begin{array}{l}\text { Health Sector } \\
\text { Development } \\
\text { Program (HSDP) } \\
\text { launched 1996/7. } \\
\text { Health Extension } \\
\text { Workers Program } \\
\text { launched by } \\
\text { Ministry of Health } \\
\text { in } 2003 . \\
\text { Human resources in } \\
\text { health crisis. } \\
\text { University medical } \\
\text { training programs } \\
\text { not in alignment } \\
\text { with national } \\
\text { priorities. }\end{array}$ & $\begin{array}{l}\text { Strong partnership } \\
\text { with University of } \\
\text { Toronto. } \\
\text { Ethiopian fellows } \\
\text { attended family } \\
\text { medicine training } \\
\text { programs in Canada } \\
\text { and the United } \\
\text { States. Persuasion of } \\
\text { Ethiopian specialists } \\
\text { of value of family } \\
\text { medicine. } \\
\text { Situational analysis } \\
\text { of Ethiopian GPs } \\
\text { by Jane Philpott } \\
\text { (Canadian MP). } \\
\text { Capacity building } \\
\text { of Ethiopian family } \\
\text { physicians by } \\
\text { Canadian family } \\
\text { physicians. } \\
\text { 2009 Ethiopian } \\
\text { Medical Association } \\
\text { (EMA) hosts } \\
\text { workshop on family } \\
\text { medicine with support } \\
\text { from University of } \\
\text { Toronto. }\end{array}$ & $\begin{array}{l}\text { Rotation of residents led to higher recruitment in family } \\
\text { medicine. } \\
\text { Significant interest in Ethiopia's family medicine programs } \\
\text { from the United States, Canada and Europe. This interest } \\
\text { has placed pressure on national government in Ethiopia to } \\
\text { advance family medicine. } \\
\text { MOH creates two more family medicine programs in two } \\
\text { universities. } \\
\text { MOH requests development of "Road Map" for family } \\
\text { medicine. } \\
\text { MOH commissions curriculum development for family } \\
\text { medicine. }\end{array}$ \\
\hline Indonesia & $\begin{array}{l}\text { Family Physician } \\
\text { Study Group } \\
\text { (KSDK) created in } \\
1981 . \\
\text { KSDK becomes } \\
\text { member of WONCA } \\
\text { in } 1984 . \\
\text { Creation of College } \\
\text { of Indonesian } \\
\text { Family Physicians } \\
\text { (KDKI) in } 2003 .\end{array}$ & $\begin{array}{l}\text { McMaster University, } \\
\text { and Faculty of } \\
\text { Medicine of Syiah } \\
\text { Kuala University } \\
\text { signed a MOU } \\
\text { to develop family } \\
\text { medicine in } 2014 . \\
\text { Family medicine } \\
\text { offered as a block } \\
\text { in undergraduate } \\
\text { curriculum beginning } \\
\text { in } 2009 . \\
\text { Creation family } \\
\text { medicine department } \\
\text { in Aceh in 2008/2009. } \\
\text { Strong partnerships } \\
\text { with primary health } \\
\text { centres. }\end{array}$ & $\begin{array}{l}\text { Family medicine department created in Aceh and seen as } \\
\text { model by national government. } \\
\text { Application for accreditation. } \\
\text { Implementation of BPJS advanced family medicine in } \\
\text { Indonesia in } 2014 \text {. UHC ensures patients receive free } \\
\text { treatment so long as they are enrolled in the scheme. } \\
\text { Regulations permit family physicians to simultaneously } \\
\text { work in public and private clinics. } \\
\text { A } 2014 \text { national policy on referrals implemented, which } \\
\text { stipulates that patients are to seek care at a health center } \\
\text { prior to visiting a hospital. } \\
\text { Implementation of law number } 20 \text { creates PHC doctor as } \\
\text { new strata of Indonesian education and will be recognized } \\
\text { in national health security system. }\end{array}$ \\
\hline
\end{tabular}

(continued on next page) 
Table 1, continued

\begin{tabular}{|c|c|c|c|}
\hline Country & Predisposing Enablers & Facilitating Enablers & Reinforcing Enablers \\
\hline Haiti & $\begin{array}{l}\text { Call for rebuilding } \\
\text { medical education } \\
\text { in Haiti after the } \\
\text { January } 2010 \\
\text { earthquake. } \\
\text { ZL partnered } \\
\text { with the MOH to } \\
\text { strengthen hospital } \\
\text { services and care } \\
\text { at hospital facility } \\
\text { seven years prior } \\
\text { to the launch of the } \\
\text { residency program. } \\
\text { The program } \\
\text { directors for the } \\
\text { new program were } \\
\text { graduates from an } \\
\text { existing successful } \\
\text { family medicine } \\
\text { residency program, } \\
\text { which meant the } \\
\text { initiative did not } \\
\text { have to start from } \\
\text { scratch. }\end{array}$ & $\begin{array}{l}\text { Ability of ZL/PIH to } \\
\text { mobilize human and } \\
\text { financial resources. } \\
\text { Visiting faculty from } \\
\text { the national medical } \\
\text { school had a unique } \\
\text { opportunity to work } \\
\text { with family doctors } \\
\text { and understand their } \\
\text { scope of work, their } \\
\text { competences as well } \\
\text { as the role family } \\
\text { doctors can play in } \\
\text { the health system. } \\
\text { Trustful and } \\
\text { long experience } \\
\text { partnership between } \\
\text { Ministere de la } \\
\text { SantePublique et de } \\
\text { la Population (MSPP) } \\
\text { and ZL/PIH. }\end{array}$ & $\begin{array}{l}\text { Strong relationship with both thenational medical school } \\
\text { and the MSPP and the recognition of the quality of the } \\
\text { program. } \\
\text { Resourced secured by ZL to maintain the quality and } \\
\text { performance of the family medicine program } \\
\text { Program recognized as one of the best family medicine } \\
\text { residency programs in the country. } \\
\text { Increasing demand for family medicine physicians by } \\
\text { hospital managers. }\end{array}$ \\
\hline Kenya & $\begin{array}{l}\text { GoK realized focus } \\
\text { on specialist care } \\
\text { was not meeting } \\
\text { need for access to } \\
\text { primary care in } \\
\text { rural areas. } \\
\text { Faith-based mission } \\
\text { hospitals run largely } \\
\text { by expatriates } \\
\text { advocated } \\
\text { for generalist } \\
\text { physicians. } \\
\text { Shift from episodic } \\
\text { care to person/ } \\
\text { community- } \\
\text { oriented care that } \\
\text { emphasized primary } \\
\text { care } \\
\text { International } \\
\text { discourse on } \\
\text { primary health care: } \\
\text { Launch of WHO } \\
\text { 2008 Report Alma } \\
\text { Ata: Now More than } \\
\text { Ever }\end{array}$ & $\begin{array}{l}\text { Team work that } \\
\text { involved stakeholders } \\
\text { that were Kenyan } \\
\text { and non-Kenyan but } \\
\text { shared the common } \\
\text { goal of developing FM } \\
\text { in Kenya. } \\
\text { Moi University } \\
\text { management } \\
\text { accepting new degree } \\
\text { in FM in Kenya. } \\
\text { Development of } \\
\text { curriculum by } \\
\text { individuals who were } \\
\text { not employees of Moi } \\
\text { University } \\
\text { Human and financial } \\
\text { resources donated } \\
\text { by non-Kenyan } \\
\text { organizations to } \\
\text { establish family } \\
\text { medicine department. }\end{array}$ & $\begin{array}{l}\text { Recognition of family medicine as a specialty by the } \\
\text { medical board } \\
\text { Registration of the Kenya Association of FPs even before } \\
\text { there were local graduates of the program } \\
\text { Support by the MoH and other stakeholders in writing the } \\
\text { Family Medicine Policy } \\
\text { PRIMAFAMED Africa Network input in facilities } \\
\text { interactions, collaboration and meetings of the department } \\
\text { in SSA } \\
\text { Moi University and other universities employing family } \\
\text { physicians from among the graduates of the Kenyan } \\
\text { program } \\
\text { MoH, PMF and INFAMED scholarship to students in } \\
\text { family medicine }\end{array}$ \\
\hline
\end{tabular}

(continued on next page) 
Table 1, continued

\begin{tabular}{|c|c|c|c|}
\hline Country & Predisposing Enablers & Facilitating Enablers & Reinforcing Enablers \\
\hline Mali & $\begin{array}{l}\text { Concept and practice } \\
\text { of community } \\
\text { medicine in place } \\
\text { (1989) prior to } \\
\text { family medicine } \\
\text { International } \\
\text { health clinical } \\
\text { training for Family } \\
\text { medicine resident in } \\
\text { Community health } \\
\text { centers in Mali } \\
\text { (starting in 1997). } \\
\\
\text { Strong friendship } \\
\text { between Malians } \\
\text { and Canadians, and } \\
\text { inspired discussions } \\
\text { around community } \\
\text { medicine and family } \\
\text { medicine. } \\
\text { Preexisting } \\
\text { community } \\
\text { medicine in Mali } \\
\text { combined with } \\
\text { international health } \\
\text { training for family } \\
\text { medicine residents } \\
\text { in community } \\
\text { health centers } \\
\text { where Canadian } \\
\text { family medicine } \\
\text { practitioners } \\
\text { intersected with } \\
\text { Malian community } \\
\text { medicine } \\
\text { practitioners. }\end{array}$ & $\begin{array}{l}\text { Bottom-up } \\
\text { approach with a } \\
\text { strong community } \\
\text { engagement. } \\
\text { Canadian support } \\
\text { to develop and } \\
\text { support the teaching } \\
\text { mission of Banconi's } \\
\text { Community Health } \\
\text { Center, precluding } \\
\text { the creation of five } \\
\text { academic CHCs. } \\
\\
\text { The DECLIC project } \\
\text { was granted in } 2010 \\
\text { and financed by } \\
\text { CIDA/DFATD/GAC. } \\
\text { Project was funded } \\
\text { generously and } \\
\text { involved development } \\
\text { of family medicine } \\
\text { department at } \\
\text { University of Bamako } \\
\text { and establishment of } \\
\text { five academic health } \\
\text { centres. } \\
\text { Program formalized } \\
\text { community and } \\
\text { family medicine. }\end{array}$ & $\begin{array}{l}\text { Influential champions played a key role. } \\
\text { Recognition by the deans of University of Bamako that } \\
\text { family medicine could offer many benefits to Mali. } \\
\text { Bottom-up approach in early phases of initiative and top- } \\
\text { down approach in the late stages of the initiative. }\end{array}$ \\
\hline $\begin{array}{l}\text { Canada } \\
\text { (Ontario) }\end{array}$ & $\begin{array}{l}\text { Province size } \\
\text { required GPs to } \\
\text { provide medical } \\
\text { care before family } \\
\text { medicine was an } \\
\text { entity. General } \\
\text { practitioners were } \\
\text { the way people } \\
\text { were getting care. } \\
\text { Because of the size } \\
\text { of the territory, it } \\
\text { was GPs practicing } \\
\text { in remote rural } \\
\text { areas; it didn't make } \\
\text { sense for specialists } \\
\text { to do this. } \\
\text { Public education } \\
\text { and awareness } \\
\text { around importance } \\
\text { of having access to } \\
\text { family physician. }\end{array}$ & $\begin{array}{l}\text { Significant } \\
\text { negotiations between } \\
\text { College of Family } \\
\text { Physicians of Canada } \\
\text { and the medical } \\
\text { students to make } \\
\text { family medicine a } \\
\text { desirable path to } \\
\text { pursue. } \\
\text { Creation of continuing } \\
\text { medical education for } \\
\text { family physicians. } \\
\text { Role of champions in } \\
\text { advocating for family } \\
\text { medicine (eg, Dr Ian } \\
\text { McWhinney). } \\
\text { Ontario government } \\
\text { policy mandating all } \\
\text { Ontarians have a } \\
\text { family physician. }\end{array}$ & $\begin{array}{l}\text { Canada (Ontario) seen as example worldwide for primary } \\
\text { care model. Spotlight on Ontario model highlighted } \\
\text { usefulness of the program and helped to sustain the } \\
\text { program. } \\
\text { Separate organizations for specialists and family } \\
\text { physicians also aided implementation of family medicine. } \\
\text { Each body of doctors belonged to their own respective } \\
\text { organization, which enabled smoother relationships and } \\
\text { negotiations. }\end{array}$ \\
\hline
\end{tabular}


Figure 1: Enabling Factors (Enablers) That Strengthen Family Medicine (Each of the Enblers is Mutually Reinforcing)

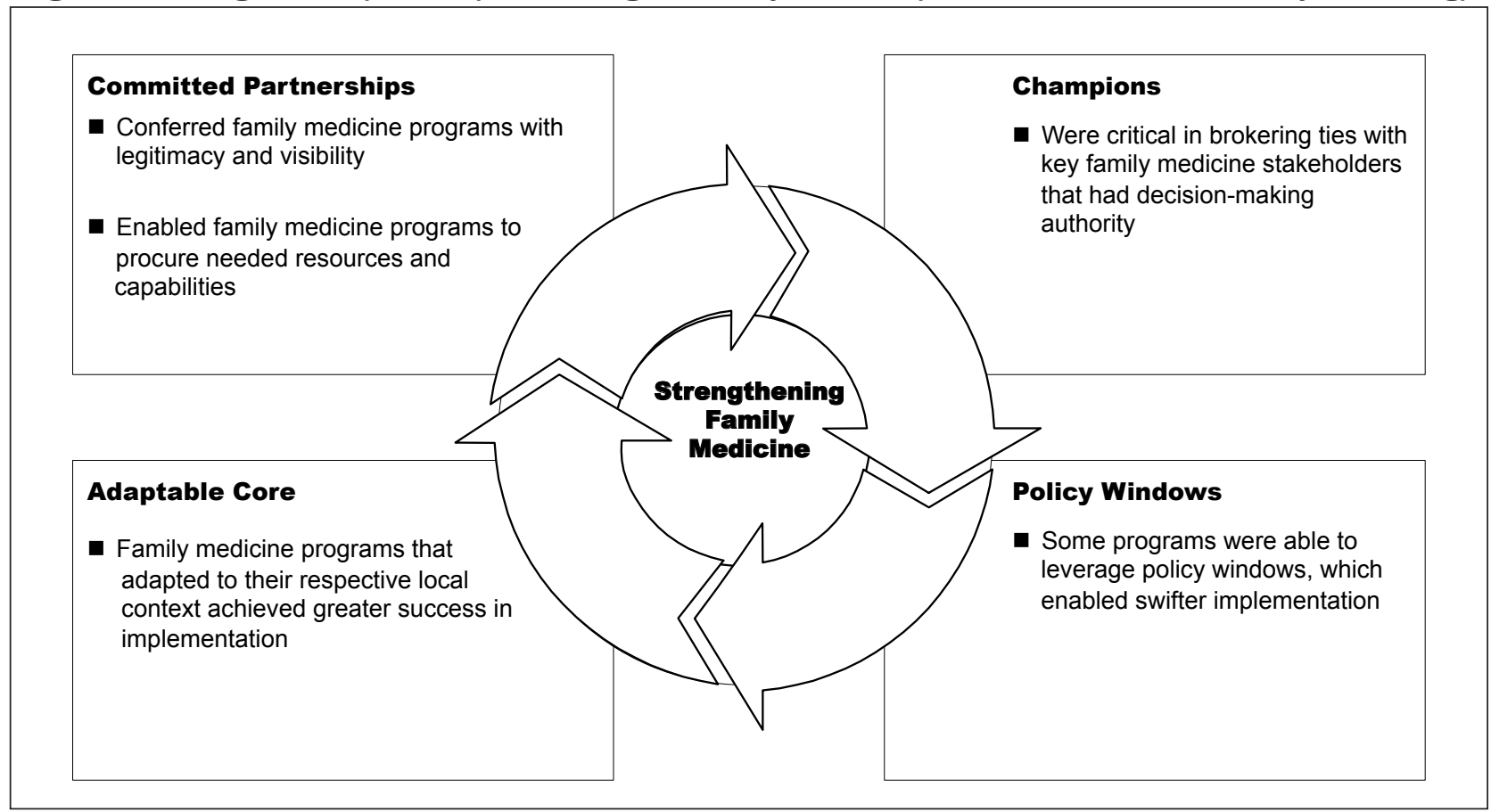

Toronto and the University of Wisconsin played complementary roles in enabling the establishment of a family medicine training program at Addis Ababa University. Champions in all seven settings provided momentum, global direction, and leadership that helped to shape the way family medicine was perceived and implemented.

\section{Committed Partnerships:}

\section{Confer Influence and Legitimacy}

All seven case studies emphasized how partnerships and alliances with influential organizations advanced implementation of family medicine. Influential partners included institutions in high-income countries with the ability to mobilize financial resources, provide expertise and capacity building support, and bolster programs' legitimacy. Partnerships with local institutions including ministries of health and local medical schools, enabled the programs to secure political support and in some cases, financial resources. In addition to extensive in-kind contribution by faculty members, family medicine programs in Haiti and Mali benefited from funding from external partners, such as Partners in Health, and Global Affairs Canada which increased the initiatives' visibility and helped garner support from ministries of health in the initial phase of implementation.

Partnerships also contributed expertise and capacity-building support. Organizations such as Partners in Health, PRIMAFAMED, and the University of Toronto helped develop curriculum and educational resources, train faculty, and provide an academic foundation to family medicine programs in Haiti, Kenya, and Ethiopia, respectively.

\section{Political Will and Policy \\ Windows: Catalyze Family \\ Medicine Initiatives}

Political will and opportune policy windows enabled the implementation of family medicine in all settings. Successfully implemented programs capitalized on opportunities presented by policy windows. Policy windows tended to occur suddenly, by chance, or due to an external crisis, and are difficult to predict.
In Haiti, the 2010 earthquake in Port-au-Prince led to health care reforms including government calls for the decentralization of medical and nurse training and the increased retention of medical professionals in the public health sector. In order to align efforts with the strategic priorities of the Ministry of Health and the needs of the population, Zanmi Lasante and its sister organization Partners in Health (based in the United States), established a residency program in family medicine at the Hospital Saint Nicolas in the town of Saint Marc.

After the tsunami and conflict in 2004, the Government of Aceh (Indonesia) allocated significant resources to the health sector. The presence and role-modelling of a Canadian family physician working with the Canadian Red Cross after the tsunami drew attention to the comprehensive scope of family medicine, and building on the emerging interest in the discipline at the government level, spurred efforts to establish family medicine training at the faculty of medicine at Syiah Kuala University in Aceh. 
In the above-mentioned cases, often unexpected and dramatic events created momentum for changes on the ground, spurred by champions and typically before formal public policy decisions to establish family medicine training. The case studies further suggest that while the family medicine initiatives were started prior to the formulation of formal policies, they were able to effectively leverage policy windows of opportunities when they arose to acquire formal support. In contrast, in Brazil, significant political and policy changes preceded and precipitated the implementation of family medicine. These included the overhauling of the health system, the creation of a tax-financed national health system, the Unified Health System (Sistema Único de Saúde, SUS), and ultimately the establishment of the Family Health Strategy which anchored the reorganization and strengthening primary care in Brazil. ${ }^{13}$

\section{Adaptable Core: Fosters Effective Implementation}

In contrast to the more catalytic and structural enablers described above, a fourth and more processfocused enabler emerged across all seven country cases, namely the ability of early family medicine training programs to remain flexible and to adapt to their local context. The case studies highlight that while the discipline of family medicine has core foundational principles, there is no unique or rigid and detailed blueprint for its development and role. Indeed, while the core of family medicine involves providing person-centered and community-based acute, chronic, palliative, and preventive care across life stages, through established relationships between patients and individual clinicians or teams, the precise scope of services provided by family physicians varies and depends on the health needs of the population and the availability and scopes of other health professions.

In Haiti for example, the curriculum was specifically designed to address the country's disease burden, such as maternal and child health, infectious diseases, and community health along with noncommunicable diseases. In Kenya, the greatest need for family medicine was in remote rural areas, and thus the family medicine training program offered at Moi University was located in a rural area. In Ethiopia, the third-year curriculum was adapted to include more surgical and obstetrics training in recognition of the need for high levels of competency in these areas for family physicians preparing to be a resource to remote populations. In other cases however, family medicine initiatives focused not only on meeting the needs of rural and remote communities, but also on the health needs of communities in urban centers. The success of early family medicine programs in our sample depended on the ability of leaders to shape and adapt the curriculum to the needs of the population rather than to conform to rigid standards developed in high-income settings.

\section{Barriers}

The barriers identified through the case studies fell into two essential groups: those representing a gap or deficit in a previously identified enabler (champions, partnerships and resources) and others (See Table 2). Barriers were noted at three levels: (1) the family medicine program itself; (2) the health care ecosystem of which the program is a part; and (3) governmental laws, policies and actions.

\section{Failing Support of Champions}

As expected, losing the support of a champion was identified as a barrier in a number of case studies. In Kenya and Haiti, support for the discipline waned after the departure of key champions. This finding highlights the importance of cultivating both individual and organizationallevel champions to minimize the impact of a single departure. ${ }^{15}$

\section{Evolving Partnership \\ Commitment}

Challenges were also identified in the ability of family medicine programs and individual champions to broker deeper institutional northsouth partnerships. In the case of Sherbrooke University for example, despite the staunch dedication of individual champions and of the Department of Family Medicine, the Faculty of Medicine was initially reluctant to allocate resources to support family medicine in Banconi, Mali. This was due in part to a misconception of the program as humanitarian aid and therefore clearly outside the core mandate of the Faculty. Ultimately, champions successfully demonstrated the mutual value of international academic collaboration to strengthen family medicine programs in line with a paradigm of capacity-building and social accountability.

\section{Lack of Resources and Expertise}

Accessing adequate financial and human resources was a common barrier amongst all seven programs. In settings where family medicine was just emerging, a lack of family physicians in sufficient numbers and with the expertise to deliver training and care according to robust family medicine principles was common.

In addition, case studies revealed that securing reliable financial support from universities and ministries of health for family medicine trainees and faculty was commonly challenging, affecting the recruitment and retention of faculty and trainees. While programs in Rio (Brazil), Haiti, and Ontario (Canada) were able to offer financial incentives to family medicine trainees, which facilitated recruitment, such incentives were not available in other countries such as Indonesia and Kenya, adding to the challenge of recruiting suitable candidates. In Aceh (Indonesia), despite a decision to begin family medicine training, the residency program is currently on hold due to a lack of government funding. 
Table 2: Barriers

\begin{tabular}{|l|l|l|}
\hline \multicolumn{1}{|c|}{ Barriers } & \multicolumn{1}{|c|}{ Level at Which Barriers Emerged } & \multicolumn{1}{c|}{ Countries } \\
\hline Resistance & $\begin{array}{l}\text { - Family medicine initiative } \\
\text { - Health care ecosystem }\end{array}$ & $\begin{array}{l}\text { Brazil, Haiti, Indonesia, Kenya, } \\
\text { Mali, Ethiopia, Ontario }\end{array}$ \\
\hline Forming partnerships & $\begin{array}{l}\bullet \text { Health care ecosystem } \\
\text { Government }\end{array}$ & Indonesia, Mali, Ontario \\
\hline $\begin{array}{l}\text { Sustaining support of } \\
\text { champions }\end{array}$ & $\bullet$ Health care ecosystem (ie, departments of medicine) & Haiti, Kenya, Mali, Ethiopia \\
\hline $\begin{array}{l}\text { Lack of resources and } \\
\text { capabilities }\end{array}$ & $\bullet \begin{array}{l}\text { Family medicine initiative } \\
\text { Government }\end{array}$ & $\begin{array}{l}\text { Brazil, Haiti, Indonesia, Kenya, } \\
\text { Mali, Ethiopia, Ontario }\end{array}$ \\
\hline
\end{tabular}

Financial sustainability of programs was identified as a challenge in four of seven case studies. In Haiti, Zanmi Lasante and Partners in Health were able to mobilize funds for a family medicine training pilot project, but have yet to secure longterm funding for the program. Similarly, the initiative in Mali, while successful in securing a grant from Global Affairs Canada, continues to grapple with the "complexities of navigating the bureaucratic systems of government funding agencies." The dependence on grants to fund family medicine training programs posed challenges for several programs and threatened long-term planning and implementation.

\section{Resistance}

All seven cases highlighted how both family medicine champions as well as faculty and family medicine graduates met resistance from other medical specialties. The lack of recognition and understanding of family medicine and the perception of family medicine as an inferior specialty made it difficult for programs to recruit trainees. In some settings, perceived competition for a limited pool of private health care dollars from the population fueled resistance to a new cadre of physicians. Resistance was also encountered within the community and among patients. In Aceh, despite the government's stipulation that initial medical consultation should occur with a family physician at a health center, a lack of trust on the part of patients frequently prompts them bypass the health center and seek care from specialists at a hospital. These findings align with the widely held assumption that insofar as primary care should be made available to the poor, it is assumed to be "poor medicine". ${ }^{14}$

\section{Discussion}

Our research findings reveal that as a new and, at times, poorly understood discipline, the establishment of family medicine in low and middle-income settings requires both macro enablers, notably supportive policy and resources, as well as micro enablers in the form of champions and experts. We found that four broad enablers were common to all seven cases, and that the interaction of enablers in each particular context was crucial to understand how and why initiatives succeeded. This is in keeping with adaptive systems theory wherein linear causality is often neither readily apparent, nor sought, but the elements that interact and the feedback loops that bind them are examinable.

The role of local champions-individuals in a position of leadership, frequently outside family medicine and in a position to leverage their formal and informal authority to promote family medicine-was key in the initial stages of development. The role of international collaborators was also highlighted as being important, typically in the context of institutional "committed partnerships". The key role of relationships anchored in a commitment to the local community is highly congruent with the nature of family medicine as a discipline rooted and defined by relationships and shaped by the local community and population. The importance of committed partnership in this study also highlights the need for time in solidifying relationships and allowing for the development of the new discipline of family medicine. The underlying principle of committed partnerships, cultivated over the long-term, is often at odds with donor preferences and frameworks, which tend to favor easily measurable health interventions that can swiftly demonstrate results. Taken together, the roles of champions and of committed partnerships depict the early development of family medicine in the settings considered in this study as emerging first from local leadership and vision and being supported, to varying degrees, by the experience and resources of the experienced partners, with the exception of Brazil. In Brazil, bold and innovative steps were taken by Brazilian family medicine visionaries to establish Family Health Teams. ${ }^{13}$ In contrast to other countries, however, the family health policy in Brazil was more clearly focused on the poor segment of the population.

Our findings challenge the idea of a linear development of family medicine and the findings of Talbot et $\mathrm{al}^{16}$ who propose that the emergence of family medicine typically starts with a clear policy decision to support its development. ${ }^{16}$ Initial conditions, while important, do not necessarily determine the direction or likelihood of success. However, when viewed through the lens of complexity, it is clear that the direction is not random. The case studies included in 
this study suggest that events and decisions closer to the ground, such as the presence of a Canadian physician in responding to the tsunami in Aceh, the development of a committed individual relationship in Mali, the catalytic involvement of a leading non-governmental organization in Haiti, and the insights of a group of general practitioners in Kenya, often play an important role prior to the formulation of policy. These very early circumstances seem to serve to prepare the setting for a more deliberate and formal decision to establish family medicine.

The cases further highlight that presenting family medicine as the solution to a problem or crisis is one way of ensuring that the initiatives had an impact. The cases suggest that policy-makers are particularly convinced where a piloted initiative demonstrates potential as a solution. In Ethiopia, policy-makers were cognizant that postgraduate medical education was not optimally aligned with the country's policies on promoting primary care. The family medicine program gradually helped to fill this policy-implementation gap. The family medicine program in Aceh, in the aftermath of the devastating 2004 tsunami, became part of a solution to the Government of Indonesia's need to provide widescale comprehensive health care in the country. The Government of Indonesia regarded the family medicine program in Aceh as a model for broader implementation in the country. Beyond this opportunistic phase, the growth of family medicine requires financial commitment from governments which may require redirecting scant resources away from entrenched funding models, a shift that can be difficult to make.

The comparative case studies offer several insight and lessons for those trying to design and implement family medicine programs. While more thorough systematic research is required, this study suggests that the following key strategies, if adopted deliberately and applied with flexibility, might facilitate the growth of family medicine globally:

- Identify and nurture champions among leaders in a variety of fields and disciplines, invest in both personal and institutional long-term relationships across high and low, or middle-income settings.

- Engage a wide array of stakeholders early, and persist even if their interest seems initially lukewarm.

- Be ready to ramp up efforts should a policy window arise.

- Be astute at recognizing and acting upon policy windows.

- Acknowledge and address capacity building.

- Be prepared to adapt, change, and rethink elements of the program if they do not meet the need of the population.

- Do not assume there is only one clear next step.

- Make sure you spend time with peers contending with similar situations as it is likely to offer validation and support, to spawn new solutions, and to generate momentum as they often share similar challenges.

\section{Conclusions}

There is much to learn about the factors that advance or hinder the implementation of family medicine initiatives globally. In discussing four key enablers (champions, committed partnerships, policy windows, and adaptable core), this study demonstrates that it is the synergistic interaction between the enablers that ultimately shapes and influences how family medicine programs are established. Future research could examine in greater depth each of the four enablers and their interaction in common contexts with regard to culture and resources.

The push for universal health coverage and the Sustainable Development Goals affirm that more deliberate, robust, and sustained efforts are needed to establish and strengthen family medicine globally.
Family medicine as a constitutive component of primary health care comprises a core aspect of universal health coverage. The findings from these case studies suggest that perhaps the creation of new funding mechanisms and partnerships to scale up family medicine globally are needed. While current global health frameworks such as the Global Fund have favored the implementation of vertical interventions, we believe the principles of health equity and access are most readily achieved through global health architecture that can bolster access to integrative primary care including family medicine. The underlying attributes of relationship-based family medicinecomprehensiveness, adaptability, and attention to both local and patient needs-are key to achieving and advancing global health priorities.

ACKNOWLEDGMENTS: Financial support was provided by the International Development Research Centre (File No. 107467-00020799028).

CORRESPONDING AUTHOR: Address correspondence to Dr Godoy-Ruiz, Department of Family and Community Medicine, University of Toronto, 500 University Avenue, 5th Floor, Toronto, Ontario, Canada M6G 1V7. 416-978-3763. Fax: 416-978-3912. paula.ruiz@utoronto.ca.

\section{References}

1. Haq C, Ventres W, Hunt V, et al. Where there is no family doctor: the development of family practice around the world. Acad Med. 1995;70(5):370-380.

2. Rouleau K. 2017 Barbara Starfield Memorial Lecture: advancing global family medicine through partnerships: stories, samba, strategies, and suggestions. http://www.sbmfc.org. br/media/17h00\%20Katherine\%20Rouleau $\% 20$ 03\%20nov\%20101.pdf. Accessed October, 2017.

3. Starfield B, Shi L, Macinko J. Contribution of primary care to health systems and health. Milbank Q. 2005;83(3):457-502.

4. World Health Organization. The world health report 2008: primary care (now more than ever). http://www.who.int/whr/2008/en/. Accessed October, 2017.

5. World Health Organization. Global strategy on human resources for health: workforce 2030. http://www.who.int/hrh/resources/pub_globstrathrh-2030/en/. Accessed October, 2017.

6. Ponka D, Rouleau K, Arya N, et al. Developing the evidentiary basis for family medicine in the global context: The Besrour Papers: a series on the state of family medicine in the world. Can Fam Physician. 2015;61(7):596-600. 
7. Beasley JW, Starfield B, van Weel C, Rosser WW, Haq CL. Global health and primary care research. J Am Board Fam Med. 2007;20(6):518-526.

8. Cooperrider DL, Whitney D. Appreciative Inquiry: A Positive Revolution in Change. San Francisco: Berrett-Koehler Publishers; 2005.

9. Leseure MJ, Bauer J, Birdi K, Neely A, Denyer D. Adoption of promising practices: a systematic review of the evidence. Int $J$ Manag Rev. 2004;5/6(3\&4):169-190.

10. Glouberman S, Zimmerman B. Commission on the Future of Health Care in Canada. Complicated and complex systems: what would successful reform of medicare look like? http:// publications.gc.ca/collections/Collection/CP3279-8-2002E.pdf. Published July 2002. Accessed October, 2017.
11. Yin Robert. Case Study Research: Design and Methods. 3rd ed. London: Sage Publications; 2003.

12. Kralj B, Kantarevic J. Primary Care in Ontario: reforms, investments and achievements. Ont Med Rev. 2012

13. Couttolenc B, Dmytraczenko T. Brazil's Primary Care Strategy; 2013. Washington, DC: The World Bank. Universal Health Coverage Series.

14. Tollman S, Doherty J, Mulligan JA. General Primary Care. In: Jamison DT, Breman JG, Measham AR, et al, eds. Disease Control Priorities in Developing Countries. Washington, DC: The World Bank; 2006:1193-1210.
15. Shaw EK, Howard J, West DR, et al. The role of the champion in primary care change efforts: from the State Networks of Colorado Ambulatory Practices and Partners (SNOCAP). J Am Board Fam Med. 2012;25(5):676-685.

16. Talbot Y, Takeda S, Riutort M, Bhattacharyya OK. Capacity-building in family health: innovative in-service training program for teams in Latin America. Can Fam Physician. 2009;55(6):613-3.e1, 6 